\title{
Forests
}

\section{Gender, property rights and access}

\author{
Yan Sun ${ }^{a}$ Esther Mwangi ${ }^{b}$, Ruth Meinzen-Dicka, Purabi Bosec, Patricia Shanley ${ }^{b}$ F. Cristina da Silva ${ }^{d}$ and \\ Trilby MacDonalde
}

\section{Key points}

- Management of forests is intimately linked to the rights and access of forest-dependent women and their families.

- Reforms in forest tenure in Africa, Asia and Latin America neglect the property rights of women and their rights of access to forest resources. Women have little say in forest governance.

- The male-female balance in forest management groups influences forest governance. The dynamics of mixed-gender groups are not well understood.

- The interface between environment and health offers a strategic opportunity to build on the strengths of forest-dependent women, mobilise support across sectors and political scales, and converge lay and professional knowledge for forest governance that takes women's interests and needs into account.

- Gender is just one factor in inequity and women are more likely to make progress by taking part in decision making processes than working outside them.

\section{Introduction}

Women's property rights and access to forest resources and the extent to which women participate in forest governance are major issues for both policy and practice.

d National Council of Extractive Populations (CNS)

e People and Plants International
Forest reforms being undertaken in Asia, Africa and Latin America, while paying lip service to equitable treatment for men and women, perpetuate arrangements that favour men.

Women often have little voice in forest governance. Even equal numbers of women and men do not necessarily equate to an equal voice and just outcomes for women. Although it is generally assumed that equitable participation of men and women in forest governance improves the way forests are managed and the livelihoods of those depending on forest resources.

This brief is based on the findings of empirical research in East Africa and Latin America (Sun et al. 2011), on the effects of reforms in forest tenure on tribal women in Rajasthan (Bose 2011) and a case study of a social movement working to make women's voices heard on forest issues in Brazil (Shanley et al. 2011).

\section{Forest reforms, property rights and access to forest resources}

Secure rights of access and use of forest resources for forest-dependent communities offers a strong foundation for good governance, improved livelihoods, better forest management and conservation (White and Martin 2002). The extent to which women's concerns are addressed in policies to reform forest tenure and manage forests varies as do the outcomes for women and for forests. Forestdependent women seldom have secure title to forest lots or secure access to forest resources.

Property rights in forests range from vast areas vested to indigenous communities to rights to share revenues from timber (Larson et al. 2010). These rights are often not only about property or ownership title but about rights 
to access and use of forest resources. National laws that reform forest tenure may consider individual, collective and public rights and control over forests and forest resources, but are generally interpreted and carried out according to local customs and byelaws. This often legalises men's existing position while undermining women's property rights and traditional rights to access forest resources.

Legislation often does not address the complexities of forest tenure and access to forest resources. Laws that allow communities and individuals to claim title do not mean indigenous groups and women necessarily benefit. Giving title often overlooks the rights of communities and women (Rocheleau and Edmunds 1997). In India, colonial legislation excluded forest communities from forests on the grounds of protecting and conserving wildlife. The 2006 Forest Rights Act reversed this, aiming to meet the needs of the scheduled tribes ${ }^{1}$ and other traditional forest dwellers, particularly women. The Forest Right Act is considered to undo historical injustice by recognising forest dependent tribal people's traditional rights to forest resources. In Nepal, although the law assigns women's groups management rights over forests, in practice the forest lots they are given are often smaller and more degraded than those assigned to male-dominated groups.

\section{Property rights and access}

Traditionally, property rights often pass down through men. Most forest tenure reforms, such as India's Forest Rights Act, promise to recognise tribal or indigenous peoples' claims to forests and land. This assumes an equal playing field for men and women. This is not the case and gender and ethnic differences undermine the effectiveness of such legislation. In Rajasthan, tribal women's identity, property, and access to forests and forest resources derive from their male relatives. In interpreting the Forest Rights Act, officials follow tradition of mainstream Indian society and give claims by tribal men precedence over claims by tribal women. This means well-to-do tribal men lay claim to forest resources, and that men claim and take control on behalf of women in the household. Where men claim title in the name of women, the women have little control over access, use, or management. Assigning rights to individuals more often than not harms the rights of women (LastarriaCornhiel 1997, Meinzen-Dick et al. 1997) as women are

1 The scheduled tribes henceforth interchangeably used with the term 'tribal people' are the so-called adivasis or original inhabitants. often ill-informed as to their rights. Illiterate tribal women, for example, believe that the Act grants only household heads, who are usually men, the right to own forestland. The socioeconomic and communication gap between government departments controlling forests and forest communities does not help. Officials and governments could help make communities and women more aware of their rights.

Before reforms, women often had a say in forest governance. Male and female elders would collectively decide on access, management and protection of forest resources. Forest committees created under reforms are mostly controlled by men, and mean that women have less influence than previously assumed. Quotas of women on executive committees may be interpreted literally. This can effectively prevent women from having a majority, for example if the quota of women is one-third. Women are at a further disadvantage because they seldom have a voice in local committees. Local committees in Rajasthan, for example, have decided to prevent tribal women collecting Jatropha seed which they used to collect in the past freely. Instead the seed is sold as a biofuel and tribal women do not share in the proceeds. Elites in male-dominated forest committees may also discriminate along ethnic and religious lines, for example between tribal women and Hindu women in Rajasthan, to the disadvantage of tribal women. Forest committees that emphasise 'equal benefits' can undermine customs that permit access to forest resources based on household needs.

Individual property rights often conflict with collective access rights. Women who depend on forest resources break the law if they take resources from private forest where they have no right of access. In some cases, rather than assigning property rights to individuals, collective title and formal rights of access may be more appropriate. Individual property rights and denial of collective access to forest resources make women more vulnerable.

Collective ownership can take account of the diversity within communities, for example differences between landowners and the landless, between dependent women and women heads of household, between men and women, and between women themselves. Tenure and access arrangements need to be adaptable to local circumstances and traditions. 


\section{Forest governance}

Forest governance policy and practice will be better informed when there is a better understanding of the workings of governance groups dominated by men or women, and groups in which there is a mix of genders, and the outcomes they achieve. A critical number of women in groups does not necessarily lead to action that makes a difference to women. Extension services biased towards men and production aspects of forests, a low profile in public spheres and cultural norms are factors affecting the low profile of women in decision making.

There are a range of views on the most effective ways for women to make their voices heard. According to women working with the National Council of Extractivist Populations in Brazil, male and some jointly-led initiatives have left insufficient space for womens' voices. Some suggest, that in certain circumstances, women-only groups, such as those focused on family issues such as health care, public policies and the environment, can be more effective to initiate change. Women-led, topic-focused initiatives have offered positive input to communities in the form of education, health care, forest product processing, trade and management. After witnessing the achievements of female led initiatives linked to health care and forests in Brazil, men are naturally drawn to the activities and welcomed. (Shanley et al. 2011). Others suggest mixed groups work better (Sun et al. 2011). Yet others argue that it is not the number of women that counts but their actions, how they organise themselves and ally themselves with others. Despite this lack of agreement, what has become clear is that rather than focusing on men or women in isolation, what needs to be examined is the relationships and interactions between them.

The accepted critical mass of women in many public forums, from local government to parliaments, is one-third (Argawal 2010). Mixed groups (one-third to two-thirds female) participate more in making decisions about forests and are more likely to have exclusive use of forests than groups with less women (Mwangi et al. 2011; Sun et al. 2011). This may be because women and men complement each other. These groups may also be better placed to tap into knowledge and services provided by external agencies.

A study of 290 forest groups in Kenya, Uganda, Bolivia and Mexico (Sun et al. 2011) found that the male-female balance influences the extent to which women are included in making and enforcing rules, and denied the use of forest resources. Groups where women dominate (more than two-thirds female) are more likely to have property rights to trees and bushes than groups where men predominate (more than two-thirds male). They collect more fuel and less timber than male-dominated or genderbalanced groups. The female-dominated groups participate less in decision making, sanction less and are less likely to exclude people from using the forest. They also invest less in improving forests. In Nepal and India, however, committees where women make up a third or more of the members regenerate forest and reduce illegal extraction of timber to a greater extent than committees with fewer women (Argawal 2010).

What is not clear is how the balance of men and women in a group affects how well a group manages forests. The relationship between the gender composition of groups and forest governance is not simple. Seasonal migration of men in search of work may, for example, mean that women make more decisions about forest management than men at certain times of year. Moreover, groups change over time. Groups dissolve, new groups emerge and membership changes. For example, in Rajasthan, tribal women as members of Joint Forest Management (JFM) village committees introduced in 1995 protected and managed forest collectively to safeguard against encroachment by non- settlers. They made rules which villagers, including men, tended to follow. The maledominated Forest Rights Act committees set up in 2006, which superseded these village level JFM committees, rather than selecting tribal women with experience of JFM for leadership, selected women with no experience.

Within the Brazilian Amazon, the first decade of leadership of extractive reserves was constituted by men. However, over the last decade, women have become leaders and are showing promise in the management of extractive reserves (Shanley et al. 2011).

\section{Women's voices in policy and reform processes}

Policy and reform processes need to take women's rights, interest and priorities into account. This means including them in making decisions that affect them. Traditionally, 
groups seeking to influence forest policy and reform have been dominated by men, for example the social movements that had a key role in shifting government policies on land and forest rights in Brazil (Souza 2008). Women, once barred from rural workers' unions and social and land reform movements, are now accepted as members but still play a secondary role. Despite their extensive knowledge of forest habitats, species and the multiple uses of forests, women seldom hold leadership positions. Poor education and invisibility in public affairs bar them from having a voice in decisions on land use and forest management. Thousands of women in the Amazon practice sustainable and multiple-use forest management on a daily basis as they rely on food, fuel and medicinal plants gathered from the forest to feed and keep their families healthy. However, they play a relatively minor role in forest policy.
This is slowly changing. In Brazil, a prominent social organisation linking social justice and environmental protection, the National Council of Extractivist Populations (CNS, formerly the National Council of Rubber Tappers) shows that women can organise, lead, build relationships with institutions and use their collective bargaining power to influence decisions that affect their interests. The CNS Secretariat of Women Extractivists has transformed the role of women within the CNS and in political hierarchies. The women chose to join forces with the vigorous women's movement in Brazil, partner with state institutions across sectors and take part in state-led decision-making processes. Rather than threatening the status quo and addressing gender-specific concerns, they are working strategically to challenge broader issues, such as citizenship and public health care, which will have a trickledown effect on forest governance and equity. Their strategy recognises

\section{Gender balance and participation in forest groups}

1. Female only groups

- Lack information and connections

- Often allocated poorer quality resources (Cornwall 2001, Pandey 1993, Rai and Buchy 2004)

- Have lower rates of enforcing rules

- Less likely to invest in regeneration

- More likely to cooperate (Eckel and Grossman 1996 cited in Molinas 1998)

- More likely to have property rights to harvest trees and bushes, and collect fuel

- More likely to have a health-based perspective on forests, with long-term benefits for the family

- More likely to speak out

\section{Mixed groups (one-third to two-thirds female)}

- Use complementary strengths (Watkins 2009)

- Capacity to manage and resolve conflicts (Westermann et al. 2005)

- More likely to monitor forest resources and impose sanctions than male or female-dominated

- Less likely to allow other groups to harvest from the forest than male or female-dominated

- Tap into knowledge and services provided by external agencies

- More likely to address topics of interest to families such as health, education and environment

3. Predominantly male groups

- Women feel isolated

- Women are less likely to speak out

- Focus on short term economic gain rather than longer-term forest benefits

- Predominant focus on timber rather than non-timber forest products

- Profits from timber sales often used for short-term, consumables (alcohol, festivities) 
that gender is just one factor in inequity and that women are more likely to make progress by taking part in decisionmaking processes than working outside them. Forestdependent women are more likely to secure their rights when they organise themselves, get involved in decisionmaking processes and become informed about the value of forests and the threats posed by changes in legislation.

\section{Change is in the air}

Rights-based approaches to property and access rights are important. Denying forest-dependent communities the right to access and manage forests exacerbates forest degradation, conflict and poverty (Larson et al. 2010). Compared to legislation, customary rules can be less stringent, promote equity and allow access to forest resources based on the needs of marginalised groups. The extent to which women can benefit from forest resources is shaped by their social status and relations, power, assets and knowledge. Women's and mixed-gender forest governance groups can be strengthened by providing them with information, technologies and training to build their capacity in ways that take into account the social and cultural constraints women face.

The roles of women in policy processes are changing. The most pressing challenges for many rural women are to feed and educate their children and keep their families healthy. In doing so, more and more women are playing meaningful roles in grass roots initiatives that link human rights with rights to natural resources. Convergence of social issues and concerns about natural resources paves the way for changes in policies to support forest-dependent women. Women can further their empowerment by strategically working on broader cross-sectoral issues and issues that directly benefit their entire families, rather than forestryspecific concerns alone.

Women in social movements involved in forest conservation in the Amazon present a good example. They are pushing for legal reforms and demolishing the boundaries between lay and professional knowledge and expertise. Women are joining forces to bring about changes in their own lives and in society. Supporting and facilitating such initiatives, such as by building organisational and communication skills, offer an alternative to projects based on rational economic models of development. The lessons emerging from Africa, Asia and Latin America are that a change in gender dynamics can come through various ways, such as removing the barriers that hinder the realisation of women's rights and access even where reforms explicitly recognise them, ensuring that women's groups are provided support through education and extension and through women's own strategic organising to influence policy makers and public policy processes.

\section{References}

Argawal, B. 2010 Does women's proportional strength affect their participation? Governing local forests in South Asia. World Development 38(1): 98-112.

Bose, P. 2011 Forest tenure reform: exclusion of tribal women's rights in semi-arid Rajasthan, India. International Forestry Review 13(2): 220-232.

Cornwall, A. 2001 Making a difference? Gender and participatory development. IDS Discussion Paper No. 378. Institute of Development Studies, Sussex.

Larson. A.M., Barry, D. and Dahal, G.R. 2010 Tenure change in the global South. In: Larson, A.M., Barry, D., Dahal, G.R. and Colfer, C.J. P. (eds.) Forest for People: Community Rights and Forest Tenure Reform. Earthscan, London. Pp: 3-18.

Lastarria-Cornhiel, S. 1997 Impact of privatization on gender and property rights in Africa. World Development 25(8): 1317-1333.

Meinzen-Dick, R., Brown, L., Feldstein, H. and Quisumbing, A. 1997. Gender, property rights and natural resources. World Development 25(8) 1305-1315.

Molinas, J. 1998 The impact of gender composition on team performance and decision-making: evidence from the field. World Development 26(3): 413-431.

Mwangi, E., Meinzen-Dick, R. and Sun, Y. 2011 Gender and sustainable forest management in East Africa and Latin America. Ecology and Society 16(1): article 17.

Pandey, D. 1993 Empowerment of women for environmentally sustainable development through participatory action research. In: Ahmed, S. (ed.) Gendering the Rural Environment: Concepts and Issues for Practice. Workshop Proceedings, 23-24 April 1993. Workshop Report \#1. Institute of Rural Management, Anand.

Pandolfelli, L., Meinzen-Dick, R. and Dohrn, S. 2008 Introduction. Gender and collective action: motivations, effectiveness and impact. Journal of International Development 20(1): 1-11.

Rai, B. and Buchy, M. 2004 Institutional exclusion of women in community forestry: is women-only strategy a right answer? In: Kanel, K. et al. (eds.) Twenty-five Years 
of Community Forestry: Contribution in Millennium Development Goal. Proceedings of Fourth National Conference of Community Forestry, August 4-6, 2004, Kathmandu, Nepal. Pp: 399-408.

Rocheleau. D. and Edmunds, D. 1997 Women, men and trees: gender, power and property in forest and agrarian landscapes. World Development 25(8): 1351-1371.

Shanley, P., Da Silva, F.C. and Macdonald, T. 2011 Brazil's social movement, women and forests: a case study from the National Council of Rubber Tappers. International Forestry Review 13(2): 233-244.

Souza, A. 2008 The gathering momentum for environmental justice in Brazil. Environmental Justice 1(4): 183-188.

Sun, Y., Mwangi, E. and Meinzen-Dick, R. 2011 Is gender an important factor influencing user groups' property rights and forestry governance? Empirical analysis from East Africa and Latin America. International Forestry Review 13(2): 205-219.

Watkins, C.A. 2009 Natural resource use strategies in a forest-adjacent Ugandan village. Human Ecology 37(6): 723-731.

Westermann, O.J., Ashby, J. and Pretty, J. 2005 Gender and social capital: the importance of gender differences for the maturity and effectiveness of natural resource management groups. World Development 33(11): 1783-1799.

White, A. and Martin, A. 2002 Who owns the world's forest? Forest tenure and public forests in transition. Forest Trends, Washington D.C. 30 pp.

This brief is based on three papers:

Sun, Y., Mwangi, E. and Meinzen-Dick, R. 2011 Is gender an important factor influencing user groups' property rights and forestry governance? Empirical analysis from East Africa and Latin America. International Forestry Review 13(2): 205-219.

Bose, P. 2011 Forest tenure reform: exclusion of tribal women's rights in semi-arid Rajasthan, India. International Forestry Review 13(2): 220-232.

Shanley, P., Da Silva, F.C. and Macdonald, T. 2011 Brazil's social movement, women and forests: a case study from the National Council of Rubber Tappers. International Forestry Review 13(2): 233-244.

INTERNATIONAL FOOD POLICY

RESEARCH INSTITUTE

IFPRI $^{\circ}$
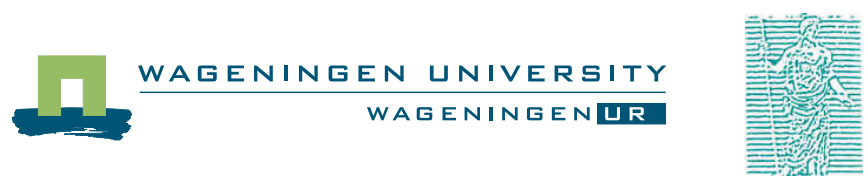